UDC 621.19:41

I. S. Aftanaziv, Dr. Sc. (Tech.), Prof.,
orcid.org/0000-0003-3484-7966,
L. I. Shevchuk, Dr. Sc. (Tech.), Prof.,
orcid.org /0000-0001-6274-0256,
L. R. Strutynska, Cand. Sc. (Tech.), Assoc. Prof.,
orcid.org/0000-0002-0401-5475,
O. I. Strogan, Cand. Sc. (Tech.),
orcid.org/0000-0002-1790-6736 DOI: $10.29202 /$ nvngu/2018-5/7

Lviv Polytechnic National University, Lviv, Ukraine e-mail: ivan.aftanaziv@gmail.com

\title{
VIBRATIONAL-CENTRIFUGAL SURFACE STRENGTHENING OF DRILL AND CASING PIPES
}

Purpose. Development of new constructions of devices for strengthening drill and casing pipes by surface plastic deformation, determination of constructive and technological parameters of vibrational-centrifugal strengthening of long-length parts.

Methodology. Based on the theory of static similarities of fatigue failure, methods for defining decreased mass and consumption of materials for cylindric parts as a result of effective strengthening of their outer and inner cylindricshaped surfaces by vibrational-centrifugal treatment are suggested.

Findings. Based on the experience of industrial use of vibrational-centrifugal treatment for strengthening plane wheel hubs and flanges, new constructive schemes of genuine devices for strengthening drill and casing pipes of exploration wells have been developed. To and durability of drill and casing pipes of exploration wells and to, The vibrational-centrifugal strengthening treatment is expedient to use during the final stage of pipes production with the purpose of increasing their reliability as well as decreasing their mass. This strengthening technology belongs to the group of dynamic methods of surface plastic deformation, features ability to dissipate considerable energy of deformation of strengthened part material in its surface layers which is equal to that of stamping. For parts made of construction steel, the vibrational-centrifugal strengthening treatment provides for the thickness of the strengthened layer within $0.15-0.20 \mathrm{~mm}$, formation of residual compressive stresses of high gradient, enhanced micro-hardness. Due to technological use of considerable inertial forces of massive strengtheners, which are rolled over the surface during the strengthening process, effective reinforcement of metal of the surface processed and formation of residual stress in their metal thickness are provided. This effective strengthening of both inner and outer long surfaces allows decreasing the mass of long-length steel parts by 15-20\%. This provides for certain economic effect related to cost of part material. For the first time, structural schemes of equipment for strengthening outer and inner cylindric-shaped surfaces of long-length parts through vibrational-centrifugal treatment have been described, including those for drill and casing pipes. The suggested constructions of strengthening equipment have a simple constructive design, do not require first line maintenance workers, and are effective and energy-efficient.

Originality. The developed designs of devices for strengthening long outer and, particularly, inner surfaces of cylindric long-length parts have no comparable counterparts internationally. Due to these designs, the spheres of effective use of surface strengthening increase considerably.

Practical value. Material capacity of long-length parts strengthened by the suggested design of strengthening equipment decreases. On a 2-3-kilometer exploration well, the decrease in the drill string mass by $15-20 \%$ as a result of strengthening treatment will allow saving about 30-40 tons of costly constructional steel. Wide industrial application of the vibrational-centrifugal strengthening and the suggested equipment for its implementation will also allow increasing reliability and durability of a wide class of long-length parts.

Keywords: surface strengthening, a long-length part, inner surface, drill pipe

Introduction. Along with drilling units and boring tools, drill and casing pipes are the most critical components of the borehole drilling process, particularly, of deep-hole exploration wells. Quite frequently, these are resisting power and reliability of these critical components that specify such significant parameters for welldrilling process as boring speed and capacity of threading a layer of high hardness, ability of a borehole pillar to stand horizontal displacements of layers of soil and rocks and others. Due to the need for resisting considerable working load, drill and casing pipes are made from qualitative construction steel of $40 \mathrm{X}$ and $30 \mathrm{XГC} \mathrm{brand;}$

(C) Aftanaziv I. S., Shevchuk L. I., Strutynska L. R., Strogan O. I., 2018 moreover, they have rather thick walls (up to $10 \div$ $15 \mathrm{~mm})$.

Regarding the current state of mechanical engineering development, there are only two realistic ways of cheapening drill and casing pipes:

- transition to manufacturing pipes using cheap materials;

- technological enhancement of resisting power of pipe material, which will allow decreasing pipe wall thickness and, consequently, their mass and costly material usage for their production.

While manufacturing these pipes for relatively shallow artesian wells, substitution of metal of drill and casing pipes for plastic mixture was opted for. Unfortunate- 
ly, resisting power of available plastic mixtures for producing drill and casing pipes for deep exploration wells is not adequate yet. That is why technological enhancement of strength characteristics of pipe metal is an option, i. e. a way of cheapening, in this case. This will allow decreasing pipe wall thickness without losses for their reliability and, consequently, consumption of costly materials for manufacturing.

Analysis of the recent research and publications. Structurally, both drill and casing pipes are made as long cylindric hollow details of annular cross-section. They are manufactured at a rolling mill followed by normalisation, natural cooling and pipe aging treatment for reassignment of residual stress in their metal thickness. In most cases in the outer zone of pipe material there are formed technological residual tensile stresses.

It is commonly known that engineering support in the outer and boundary layers of material of metal parts of compression stress can resist devastating impact of working load to the fullest extent. That is why finishing and strengthening operations are introduced in the process of manufacturing metal parts, particularly steel ones, with the purpose of improving properties and quality of outer layers of the material of the parts.

Among various finishing and strengthening operations for metal parts, thermal operations and reinforcement of outer layers of the part material with surface plastic deformation have become routine methods.

Certain restrictions as for surface strengthening of drill and casing pipes exist regarding the variety of surface plastic deformation. First of all, only methods of the dynamic strengthening group are applicable here. Improvement of strength characteristics of pipe material outer layers and formation of residual compressive stress of high gradient are of the essence. However, not every common dynamic method for surface strengthening is suitable for strengthening treatment of such specific parts as drill and casing pipes. Among the known kinds of dynamic strengthening methods by surface plastic deformation (SPD) only stamping [1] and vibrationalcentrifugal treatment (VCT) [2] could meet high requirements for indicators of energy of strengthening deformation and treatment class provided regarding the pipes. Nevertheless, it is understood that due to extremely low efficiency of strengthening stamping, this is expedient to use only for strengthening threaded hollows of drill and casing pipes. For the outer zone of the pipes with a length up to $11.5 \mathrm{~m}$, stamping is not suitable.

The vibrational-centrifugal strengthening (VCS) treatment developed at Lviv Polytechnic National University organically combines two such important technological parameters as high efficiency of strengthening treatment along with considerable strain energy. High efficiency of the VCS treatment was proved by its successful use for plane wheel hubs and flanges and sleeves of boring pumps [3]. VCS of the outer surface and radius blends made of light structural alloys of plane wheel hubs and flanges has doubled the life time of these critical components compared to strengthening by roller burnishing. Moreover, resistance to abrasive wear of steel sleeves of boring pumps has increased one-and-ahalf to two times as a result of strengthening their outer surface through VCT [4, 5].

Therefore, there is every reason to consider the use of the VCT to be promising for efficient strengthening with the purpose of decreasing the mass and increasing reliability and durability of drill and casing pipes.

However, both the experience of industrial use of VCS for treating drill and casing pipes and equipment constructions for efficient strengthening of the surface of such long parts are lacking.

Objectives of the article. The objective of the research is to develop constructions of highly-efficient strengtheners for surface plastic deformation of the material of drill and casing pipes. Due to considerable strain energy, the strengtheners are to provide formation of residual compressive stress of high gradient and enhanced micro-hardness of their material in outer layers of strengthened material, which will eventually contribute to increasing reliability and durability of these and other critical long-length parts.

The main tasks of the research included:

- development of structural schemes of strengtheners for strengthening outer and inner layers of cylindric long-length parts through SPD;

- development of mathematical relation in order to determine the main technological and structural parameters of vibrational-centrifugal strengtheners of long-length parts;

- development of methods for forecasting decrease in the weight of cylindric long-length parts due to qualitative surface strengthening of their material.

Presentation of the main research. The idea of applying inertial forces of planetary rolling motion of massive impact body as a source of energy while contacting with the surface of the treated part because of an insignificant number of distorted elements was taken as a base of suggested constructions of strengtheners of long-length parts to which drill and casing pipes belong [6].

Fig. 1 shows a basic structure diagram for strengthening the surface of drill and casing pipes.

The device is equipped with resiliently fixed on the base 1 on pneumocylinders 2 of platforms 3 and 4 , one of which, for example, the left one, is fixed with a possibility of moving vertically, and the other one - in a horizontal plane. Displacement of the platform 3 in a vertical plane to one of two end positions (above the platform 4 or below) is performed by changing the air pressure in the pneumocylinders on which it is fixed. Displacement of the platform in a horizontal plane along the base is done with a support 5 which is bolted on the base in different positions. Displacement of the support 5 along the base is done with the help of a motion screw 6.

On both platforms there are fixed balance weights of vibration exciters and between the platforms there are rigidly fixed drill and casing pipes 7 . In this particular case, the number of simultaneously strengthened parts equals three; however, it can be larger for operational reason.

The vibration exciters placed on each platform include a frame fixed on the rolling-contact bearing on an 


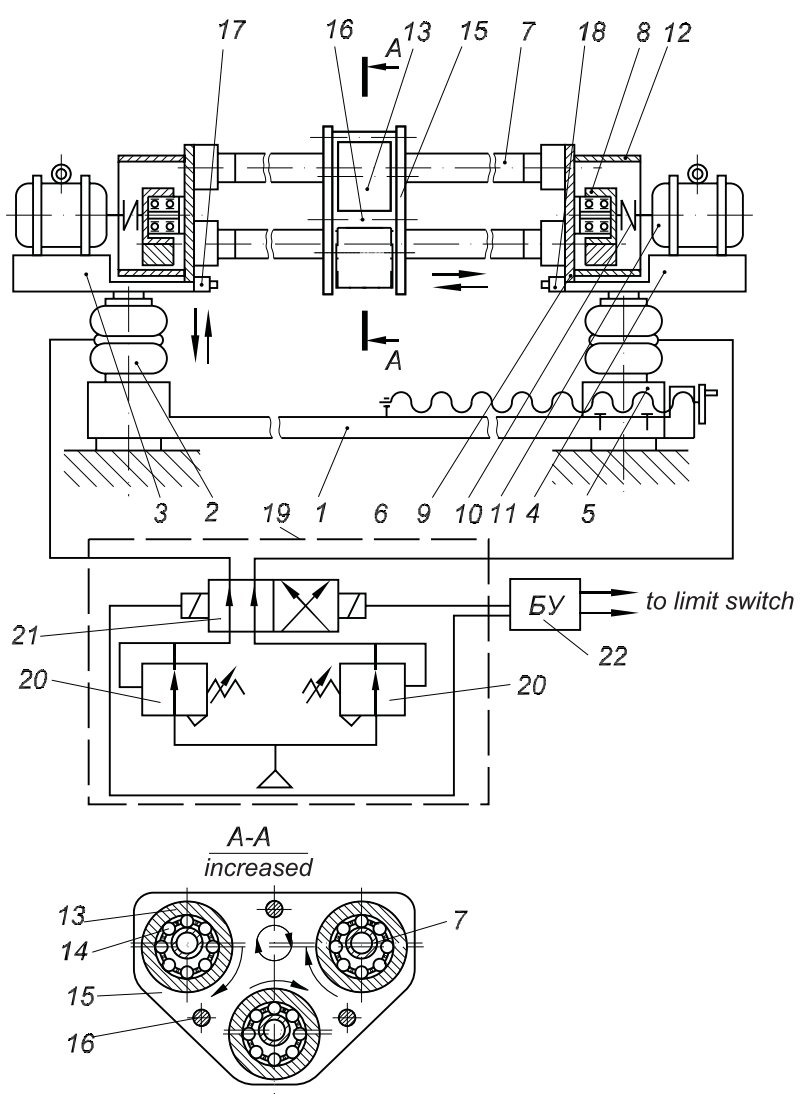

Fig. 1. Basic diagram of a vibration machine for strengthening the surface of drill pipes

axis 8 ; on the frame there is fixed a balance weight 9 . The rotational motion of the vibration exciter housings is provided by electric motors 11 through elastic couplings 10 . The shafts of both electric motors rotate in the same direction, at the same rate and through the same angle. The vibration exciters are covered with protective covers 12 .

On each of the parts to be machined there is loosely fixed one roller 13 with processing balls 14 placed in a separator plate; hardness of the balls is larger than that of strengthening part material. The diameter to which the processing balls are placed in the separator plate is chosen regarding the required mode of vibration support of roller rotation while providing machined parts with oscillation of specified amplitude. The mass of the roller 13 and frequency of its rolling is set experimentally depending on the strengthening part material and required quality parameters for strengthening treatment in the outer layer of the part material. The rollers are assembled in one unit with the help of flanges 15 and spacer sleeves 16; the unit is based on them with the help of guiding rollers (not shown in the figure) in order to avoid surface damage of the parts.

On either of the platforms there are fixed limit switches 17 and 18 which give an electric signal to a command-apparatus 19 when on impact with the flanges 15. The command-apparatus 19 is intended to change the air pressure in the pneumocylinders 2 of the left platform 3 and consists of pressure control valves 20 which regulate the air pressure in the pneumocylinders of the platforms, a pneumatic electric spool 21 and a pneumatic electric spool control block 22 .

Strengthening of drill pipes is performed in the following sequence. On the pipes, which are to be strengthened, there is fixed a unit with rollers. The drill pipes are fixed on the platforms with the help of collect chucks and the balance weights of vibration exciters are given rotational motion by applying voltage to the electric motor winding. Balance weight rotation causes excitation of circular plane-parallel vibration of the drill pipes with specified amplitude; the square area of the pipes is orthogonal to their centre lines. Influenced by vibration of the treated pipes the rollers 13 , which are fixed on them, get involved in the mode of vibration support of their rotation, which is accompanied by rolling over the outer strengthened surface. Rolling of the rollers occurs to the processing balls 14 placed in their separator plate with an impact; as a result, the pipe material is plastically strained and strengthened in places of contact.

Positioning the platforms 3 and 4 at different levels provides for vertical lean of the pipes being treated within $5 . . .6^{\circ}$ to the platform 4 . The unit with the roller under the action of its attractive force moves towards the platform 4 . Reaching the limit switch 18 fixed on the platform 4 , the flange 15 of the unit acts on the rod of the switch and closes its contacts. The signal arrives at the command-apparatus 19 , the pressure in the pneumocylinders 2 of the platform 3 changes, the platform comes down to the extreme position reversing the deflection angle of the parts in process and the direction of movement of rollers over the processed surface.

The number of movements of the unit with the rollers over the pipes being strengthened, traverse speed of the unit which is set by the deflection angle of the parts as well as the roller weight, vibration frequency of the platforms and time of strengthening are determined experimentally in each specific case relative to the material of the parts being strengthened and required quality parameters of the strengthening treatment.

Rolling of the rollers and their movement over the processed parts provide for uniformity of strengthening over the surface strengthened. The thickness of strengthening of the outer layer material of steel pipes up to $0.2 \ldots 0.25 \mathrm{~mm}$ a with cold work hardening degree of $20 . .25 \%$ is obtained through mutual collision of the rollers and the parts while contacting through an insignificant number of processing balls.

Displacement of the platform 4 along the base 1 with the help of the motion screw 6 and use of the rollers with different diameters makes it possible to strengthen drill pipes of different length and diameter, which increases technological opportunities of the method considerably.

Fig. 2 shows a basic structure diagram for strengthening the surface of casing pipes while giving a strengthening tool - a rolling element - a generating motion by making an electromagnetic field influence it. Like the construction for strengthening drill pipes considered above (Fig. 1), the device is equipped with platforms resiliently fixed on the pneumocylinders, the commandapparatus for changing the deflection angle of the parts being treated in a vertical plane, fixed limit switches for 


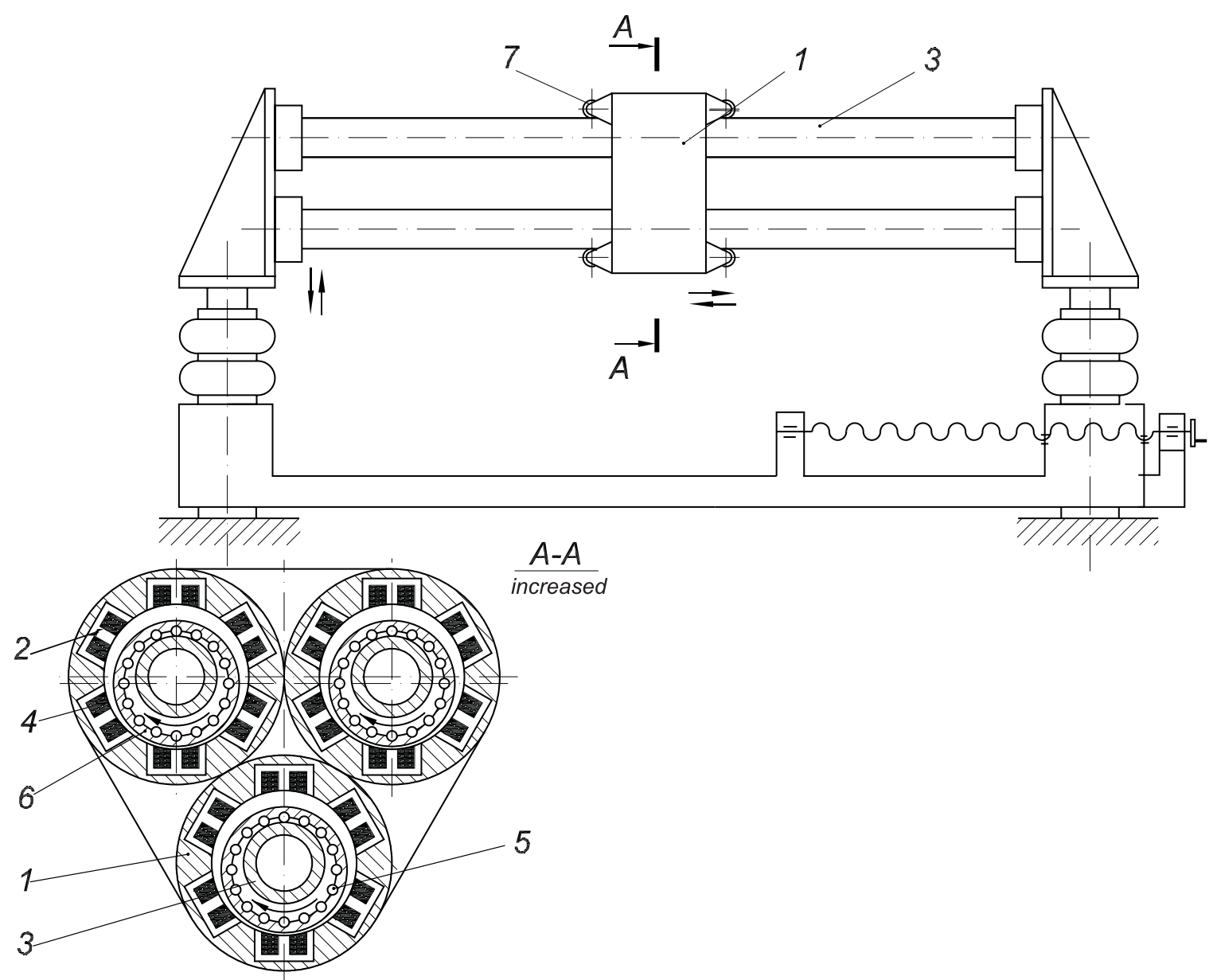

Fig. 2. Basic diagram of a processing device with electromagnetic gear for strengthening pipes

giving a signal to the command-apparatus and mechanisms of workholding and displacing one of the platforms along the base, which makes it possible to strengthen pipes of different length.

Distinctive features of the device include absence of unbalance vibration exciters with electric motors of their driving and availability of electromagnets 2 assembled in a housing 1 . Each of the processed parts 3 having their outer layer strengthened is enclosed by six electromagnets regularly spaced circle-wise; the coils of the electromagnets are connected in such a way that they form three two-cycle vibration exciters shifted to each other by an identical angle. Among the electromagnets covering the processed parts there is a loosely fixed roller 4 with strained bodies 6 (steel heat-treated balls) placed in its separator plane 5 . The housing is based on the pipes being strengthened on guiding rollers 7 .

When strengthening the outer zone of casing pipes, the housing 1 with electromagnets 2 and rollers 4 are fixed on tubes 3 which are further fixed on the platforms of the device. The platforms are placed at different levels relative to the base. When applying voltage to the electromagnet coils, the rollers being attracted by magnetic adhesion to each of them alternately, are drawn in the rolling over the outer layer of a strengthened pipe which comes over strained balls standing out from the separator plate. At places of contact with the strained balls, the material of the part is plastically strained and strengthened. Since the platforms are placed at different levels, the housing 1, being under the action of attractive force, along with the rollers 4 moves on roll pins over the processed surface generator of the pipes to the platform which is situated below at this moment. Having shifted to this platform, the housing 1 influences the limit switch, which gives a signal to the command-apparatus. Pressure in the pneumocylinders changes, the deflection angle of the parts processed reverses and the housing shifts to the opposite platform. Uniformity of strengthening the pipe surface is provided by rotation of the rollers and their moving over the processed surface generator. The thickness of the strengthened layer and degree of the cold work hardening are regulated by changing the mass of the roller, the number of repeated moves of the rollers over the surfaces processed.

When strengthening the inner layer of casing pipes (Fig. 3), the housing 1 with electromagnets 2 and rollers 4 is placed inside the processed parts 3 . Here with the purpose of increasing technological possibilities of the device, it is worth using two series of electromagnets placed in each of the parts processed with their coils interconnected in parallel.

The roller 4 with the separator plate 5 and strained balls 6 is placed amidst the series of electromagnets while one anchor 8 each is attached to the roller end; the 

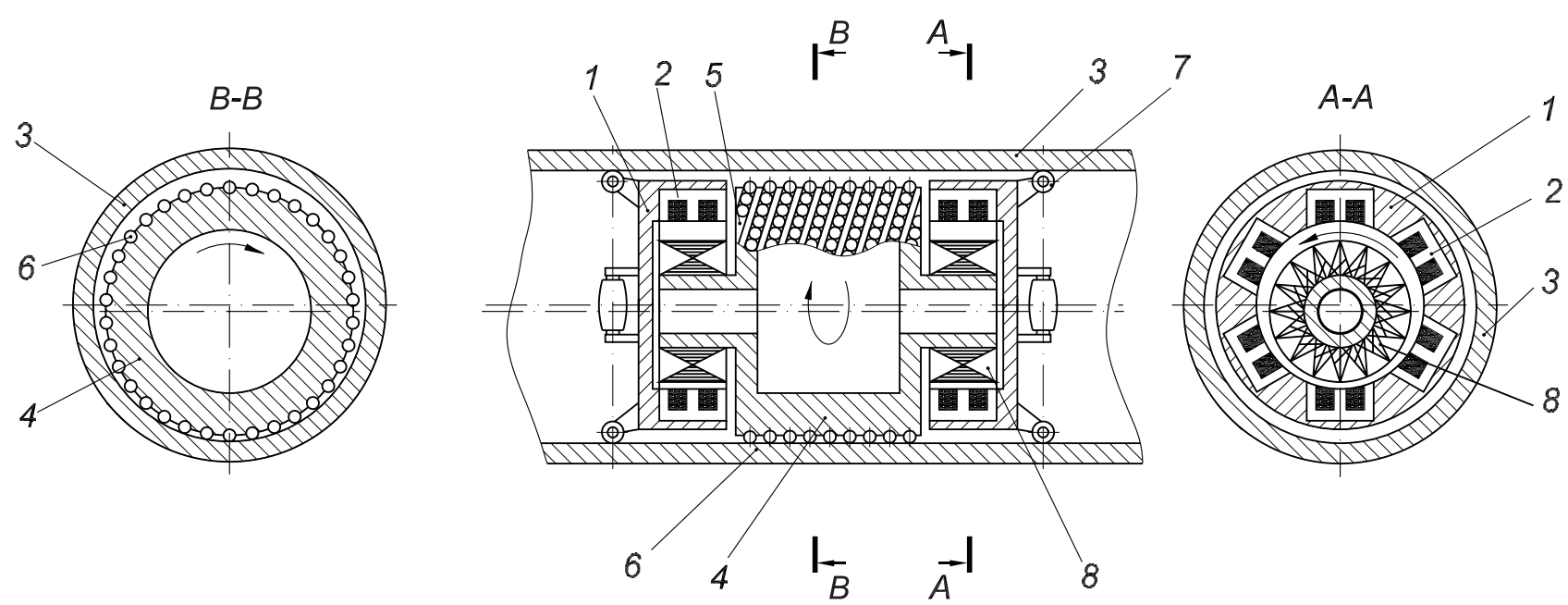

Fig. 3. Strengthening of the inner layer of casing pipes

anchors are made of transformer sheet iron and are put into the central zone of each electromagnet series. The housings 1 are based in the parts being processed on the guiding rollers 7 .

When voltage is applied to electromagnet coils, the anchors 8 being pulled to each of the coupled electromagnets in turn, rotate. Along with them the roller 4 , to whose ends they are attached to, rotates. Rotation of the roller is accompanied by its rolling over the inner face of the strengthened pipe which comes over strained balls 6 standing out from the separator plate 5 . The mechanism of strengthening the pipe surface and the nature of the roller's axial displacement along the part being strengthened as well as their sequence are similar to those in the device for strengthening the part outer face described above.

Fig. 4. presents one more basic structure diagram of the strengthener of the outer face of drill and casing pipes.

The main structural components of this strengthener are two housings set on the tubular base with a bevel gear wheel of the rotary actuator, the drive itself in the form of the electric motor, coupling and driving bevel gear wheel as well as cylinder-shaped strengtheners, which are connected with the rolling housings by corrugated

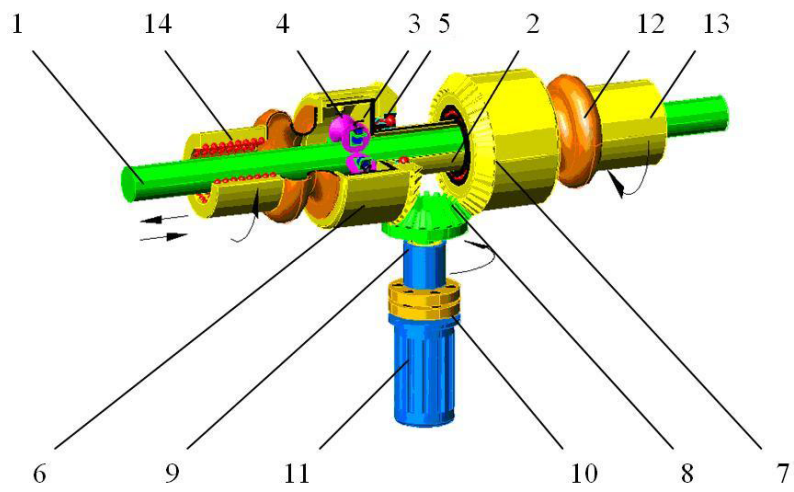

Fig. 4. The model of the strengthener for surface strengthening by plastic deformation of the outer surface of drill and casing pipes pipes, along with strained elements in the form of steel heat-treated balls of high hardness.

The tubular cylindrical base 2 is set on the strengthened surface of the processed part 1 with the help of centring roll pins 4 actuated by springs 3 . On the tubular base 2 on bearings 5 there are placed two housings 6 in coaxial relationship with the geometrical axis of the part being processed. On either of the housings 6 there is rigidly fixed one toothing rim of the bevel gear wheel 7 . The toothing rims of the bevel gear wheel 7 are placed opposite one another. They have the common point of intersection axes of their toothing rims and they form two bevel gearings of the drive together with the driven coneshaped gear wheel 8 , which is geared to them. This location of the toothing rims of the bevel gear wheels provides for counterrotation of the housings 6 about the part 1 being processed. The driven cone-shaped gear wheel 8 geared to the bevel gear wheels 7 is fixed in the bearings on the static base 9 , while its shaft end portion is attached to the electric driving motor 11 by the coupling 10; the electric driving motor 11 is set on the static base (not shown in the Fig. 4).

The strengthening device is based on the processed part 1 with the help of the centring roll pins 4 actuated by the springs 3 which simultaneously provide for stationing of the strengthener on the surface of the part 1 .

The actuating work tool of this device is made of massive cylinder-shaped strengtheners 13 on the outer surface of which in separator cavities there are fixed deformable bodies (DBs) 14 with axial rotation; the DBs are in the form of steel heat-treated balls of high hardness. The cylinder-shaped strengtheners 13 are attached to either of two housings 6 through an elastic resilient member 12, for example, corrugated rubber bellows. Such implementation allows the strengtheners to have capacity for shifting towards the axis of the part 1 being processed (Fig. 5) apart from rotational motion with the frequency equal to the rotation frequency of the housings 6 . The numbering of positions in Fig. 5 corresponds to the numbering in Fig. 4.

The deformable elements in the form of steel heattreated balls 14 of high hardness are set for their axial 


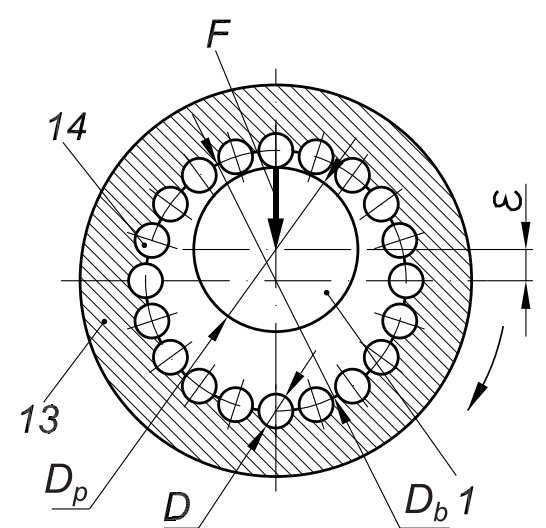

Fig. 5. Schematic cross-section of the strengthener 13 with deformable steel balls 14 (legends from Fig. 4)

rotation in the separator cavities on the outer surface of the cylinder-shaped strengtheners 13 on the diameter which is equal

$$
D_{b}=D_{p}+\varepsilon+D,
$$

where $D_{p}$ is the diameter of the processed surface of the part $1 ; \varepsilon$ is the eccentricity of the strengthener 13 relative to the geometrical axis of the processed surface of the part $1 ; D$ is the diameter of the deformable elements in the form of steel heat-treated balls which is mostly chosen from the ratio $D=(0.15 \div 0.20) D_{p}$ from the range of $D=10 \div 15$ mm (Fig. 5).

The cylinder-shaped strengtheners 13 are loosely set on the part 1 being processed for rotation about the axis of the strengthened surface with the eccentricity $\varepsilon$. In Fig. 4 the direction of rotation of strengtheners 13 with DBs 14 , driven gear wheel 8 and axial displacements of the processed part 1 is indicated with arrows.

Strengthening treatment of the outer cylindricshaped surface of long-length parts, including drill and casing pipes, by the device under consideration is performed in the following way. The pipe 1 to be strengthened is placed amidst the strengtheners 13, resilient members 12 and the base 2 with its processed outer cylindric-shaped surface being amidst the centring roll pins 4 (Fig. 4). After switching on the electric driving motor 11 , the rotational moment and rotational motion are applied to the driven gear wheel 8 from the shaft through the coupling 10 . Through the toothing rim, rotation of the gear wheel 8 is transferred to bevel gear wheels 7, which counterrotate with the housings 6 about the strengthened pipe 1 . Through the resilient members 12 , the rotational moment is transferred to the strengtheners 13 , which gains the rotational motion about the strengthened surface of the pipe 1 being processed.

Under the action of centrifugal forces, the axial rotation of the massive strengtheners 13 is transformed into the rolling motion of the strengtheners by the DBs 14 fixed on their inner surface over the strengthened surface of the pipe 1 . This is stimulated by the eccentricity $\varepsilon$ of the strengtheners 13 relative to the processed surface of the pipe 1 . During the strengthening treatment at any time, the strengthener 13 contacts the strengthened surface of the pipe 1 through an insignificant number of the
DBs 14 , which are placed along the generating lines of the inner surface of the strengthener 13 and the surface processed. Due to the availability of compound rolling motion of the strengthener 13 , which switches both its geometrical axial rotation and its redial motion relative to the processed surface of the strengthened pipe 1 simultaneously, making contact of a successive group of the DBs 14, which are placed along the generating line of the strengthener 13 , with the processed surface of the pipe 1 occurs with an impact (Fig. 5). At the same time the strengthener 13 is affected by the centrifugal force $F$, whose rolling action vector is directed from the centre of the mass of the strengthener and runs perpendicular to the geometrical axes of the strengthener and the processed surface [7]. The centrifugal force direction is indicated with an arrow with the letter symbol $F$, and its value $F$ is proportional to the mass $m$ and the eccentricity $\varepsilon$ of the strengthener and the square of circular frequency $n$ of its rolling motion and is determined from the relation

$$
F=m \cdot \varepsilon \cdot \omega^{2},
$$

where $\omega=2 \pi n$ is the circular frequency of the rolling motion of the strengthener $13 ; n$ is the rolling frequency of the strengthener 13 over the processed outer surface of the pipe 1 ; $\varepsilon$ is the eccentricity of the strengthener 13 relative to the geometrical axis the processed surface of the pipe 1 ; $m$ is the mass of the strengthener 13 with the DBs 14 .

The regulatory quality of the strengthening treatment, namely, the thickness of the strengthened layer of the material on the processed surface and ensured level of residual stresses, straining force, i.e. impact force which falls on each of the DBs and is proportional to the centrifugal force $F$ acting on the rolling strengthener 13 , and is inversely proportional to the number $N$ of the DBs 14 placed along the generating line of the strengthener, that is

$$
F_{i}=\frac{F}{N}=\frac{m \cdot \varepsilon \cdot D \cdot \omega^{2}}{l},
$$

where $l$ is the length of the generating line of the cylinder-shaped surface of the strengthener 13 , on which the DBs 14 are set.

As DBs 14 in the device considered steel heat-treated balls of high hardness are mostly used. That is why impact interaction of the DBs 14 with the surfaced of the processed pipe 1 whose material is not as hard as that of the steel balls is evident formation of considerable contact stress at points of contact of the balls 14 with the processed pipe 1 material; under the action of the contact stress the processed part material is plastically strained and strengthened. The value of the contact stresses, which occur at points of contact with the DBs 14 in boundary layers of the surface material of the processed pipe 1 , as a result of impact interaction, is determined the relation. $\pi$

$$
\sigma_{c o n}=\frac{F_{i}}{S}=\frac{10 \cdot m \cdot \varepsilon \cdot D \cdot n^{2}}{l \cdot d^{2}}
$$

where $S=\frac{\pi d^{2}}{4}$ is the square area of the residual impression after an impact contact with the deformable spheri- 
cal body (ball 14); $d$ is the diameter of the impression on the processed surface, as a result of an impact contact of the DB 14 with the pipe 1 being strengthened.

Here the basic design parameters of the strengthener include:

- the eccentricity $\varepsilon$ of the strengthener;

- the number $N$ and the diameter $D$ of the DBs equipped on the strengthener.

The basic technological parameters of the strengthening the outer cylinder-shaped surface of long-length drill and casing pipes by plastic deformation which are essential for the ultimate quality of strengthening treatment in the process considered are [7]:

- impact force $F_{\mathrm{i}}$, which falls on each of the DBs and mostly depends on the mass $m$ of the strengthener;

- rolling frequency $n$ of the strengthener over the outer surface of the strengthened pipe;

- speed of the axial movement of the processed part relative to the strengthener or vice versa - that of the strengthener relative to the processed part;

- the number of redrawing passes, i.e. recurrent shifts of the strengtheners along the generating line of the processed surface of the part.

Thus, change in such design parameters as mass $m$ and the eccentricity $\varepsilon$ of the strengthener conditions change in the force $F_{\mathrm{i}}$ of impact interaction with the strengthened part material and, correspondingly, the value of the contact stresses $\sigma_{c o n}$, which are formed in the outer zone of the metal of the strengthened part at points of contact with the deformable spherical bodies. The process is implemented rather simply through attaching extra loads to the strengthener 13 , which increases its mass and, consequently, contributes to increasing the centrifugal force $F$ and force of impact interaction of the strengthener with the material of the processed part 1 , which is inextricably connected with the centrifugal force. The recurrent shifts of the processed part 1 over the strengthening device (or vice versa), i.e. redrawing passes, improve uniformity of the strengthening treatment.

From the literary sources it is known that qualitative surface strengthening of parts does not only provide for their increasing reliability and durability but is also able to decrease the mass of strengthened parts due to improvement of the mechanical properties of metal in their outer and boundary layers. This is proven demonstratively both by fatigue testing of real strengthened parts $[8,9]$ and by numerous laboratory fatigue testing of samples of different materials, which were subject to surface strengthening by various methods. Results of these research studies are widely presented in works by national and foreign researchers. Thus, Borodin N.A., Stepanov M. N. and Khazanov I. I. proved that surface strengthening increases durability of large-format parts from nonferrous metals and alloys, in particular, magnesian and aluminium wheel hubs of planes. Kudriavtsev I. V., Kravchuk V. S. [10], Kaledin B. A. and Chepa P.A. proved in their research that surface strengthening of steel parts can enhance their durability and resistance to wear-out. Meanwhile basing on fatigue testing strengthened steel samples, Oliinyk N.V. and Krav- chuk V.S. developed a theory of the so-called 'static similarities of fatigue failure' in their work 'Reduction in consumption of materials for parts strengthened by surface plastic deformation'. They proved that due to increasing fatigue endurance of parts, which is ensured by strengthening, it is possible to considerably decrease the cross-section area of heavy-loaded steel parts and their mass. Their theoretical and experimental studies demonstrated that as a result of qualitative strengthening of steel parts by SPD, fatigue micro-crack initiation shifts from the outer zone to deeper boundary layers. Moreover, the rate of fatigue micro-crack initiation and growth decreases considerably as well as the rate of their transition from being micro to destructive fatigue macrocracks. Consequently, the so-called 'median' endurance strength increases, and, eventually, fatigue endurance of the material of parts grows.

Analysing possible decrease in the mass of a part as a result of surface strengthening, the researchers recommend [10] proceeding from the assertion tested by physics of metals that 'fatigue endurance of a strengthened part with the changed mass will be ensured provided the product of its median endurance strength is retained at the same level at the modulus of section as that of a unstrengthened part, that is

$$
\bar{\sigma}_{-1 s} \cdot w_{2}=\bar{\sigma}_{-1 u} \cdot w_{1},
$$

where $\bar{\sigma}_{-1 s}$ and $\bar{\sigma}_{-1 u}$ are median endurance strengths of the material of the strengthened and unstrengthened parts, correspondingly; $w_{1}$ and $w_{2}$ are the modulus of section of the unstrengthened and strengthened parts, correspondingly.

Then, the value of the strengthening factor can be presented as

$$
\beta=\frac{\bar{\sigma}_{-1 s}}{\bar{\sigma}_{-1 u}}=\frac{w_{1}}{w_{2}} .
$$

In general casing and drill pipes of exploration wells as machine parts are made as thin shells of rotation whose modulus of section is equal to

$$
w=\frac{\pi d_{1}^{3}}{32}\left(d_{1}^{4}-d_{2}^{4}\right),
$$

where $d_{1}$ is the diameter of the outer zone of a casing or drill pipe; $d_{2}$ is the diameter of the inner surface of a casing or drill pipe in the same section.

Since the standards for drill and casing pipes strictly specify their outer diameters, it is possible to decrease their mass by decreasing the pipe wall thickness, i.e. by increasing the inner diameter

$$
\beta=\frac{w_{1}}{w_{2}}=\frac{d_{1}^{4}-d_{2 s}^{4}}{d_{1}^{4}-d_{2 u}^{4}},
$$

where $d_{2 u}$ and $d_{2 s}$ are the inner diameters of unstrengthened and strengthened pipes, correspondingly.

The mass of the unstrengthened pipe is

$$
m_{1}=\frac{\pi \cdot \rho \cdot l}{4}\left(d_{1}^{2}-d_{2 u}^{2}\right),
$$


while the mass of the strengthened pipe is

$$
m_{2}=\frac{\pi \cdot \rho \cdot l}{4}\left(d_{1}^{2}-d_{2 s}^{2}\right)
$$

where $\rho$ and $l$ are the material density and the length of the pipe, accordingly.

Then it can be written as

$$
\frac{m_{1}}{m_{2}}=\frac{d_{1}^{2}-d_{2 u}^{2}}{d_{1}^{2}-d_{2 s}^{2}} .
$$

Having performed basic mathematical transformations of formulas (1) and (2) and set $K=\frac{d_{1}^{2}+d_{2 u}^{2}}{d_{1}^{2}+d_{2 s}^{2}}$ we obtain an expression for calculating the mass change for the casing or drill pipe as a result of its strengthening by VCT

$$
m_{2}=\frac{K \cdot m_{1}}{\beta} .
$$

Formula (3) shows interrelation between a possible decrease in the mass of the drill or casing pipe as a result of decreasing its wall thickness while retaining strength characteristics of the pipe due to its qualitative strengthening of by SPD including strengthening by VCT.

Experimental studies show that the value of the $K$ is within $0.95 \div 0.99$, while the strengthening factor of the part is $\beta=\frac{\bar{\sigma}_{-1 s}}{\bar{\sigma}_{-1 u}}$, depending on the treatment mode it is within $K=0.2 \ldots 0.25$. Consequently, the mass of drill and casing pipes can be decreased by $15-20 \%$ as a result of their surface deformation. For a static exploration well with the drill pipe diameter of $\varnothing 100 \mathrm{~mm}$, casing pipe diameter of $\varnothing 300 \mathrm{~mm}$ with conventional pipe wall thickness of $10 \mathrm{~mm}$, metal mass decrease at every one meter of the well makes $15-20 \mathrm{~kg}$ as a result of surface strengthening. This will make $30 \div 40$ tons of steel for a $2 \div 3$-kilometre well and, consequently, $300 \div 400$ thousand US dollars' cost cut on each exploration well.

Therefore, summing up it is worth mentioning the following. First of all, attention should be paid to developing a new method of surface strengthening of parts of circular section, which the authors called 'vibrationalcentrifugal strengthening treatment'. A specific distinctive feature of this strengthening technology is giving a massive strengthening tool rolling motion over the surface being strengthened. As a result, the strengthened surface is affected by considerable dynamic loads, which provides for qualitative strengthening of parts with high gradient of residual compressive stress and micro-hardness in outer and boundary layers of the strengthened part material.

Another positive aspect is development of a series of construction diagrams of equipment for surface strengthening by VCS treatment of outer and inner surfaces of long-length parts. While surface strengthening treatment of steel long-length parts could be implemented more or less successfully by some of numerous strengthening methods, for example, bead blasting or shock-vibrating machining, the devices for strengthening the elongated interior face are suggested for the first time. They have no comparable counterparts among strengthening equipment internationally. This opens extraordinary prospects for technological enhancement of reliability and durability of such specific long-length parts as tank and artillery gun tubes [11], casing pipes, high-pressure pipes and others through strengthening them. Moreover, suggested devices have a simple constructive design and can be installed at any machine-building enterprise.

The suggested decrease in specific material requirement for drill and casing pipes for exploration wells due to the strengthening by VCT is no less important. Saving $30 \div 40$ tons of costly steel on the mass of drill and casing pipes, that is about half a million US dollars on every exploration well, would be highly relevant for the state.

All above-stated proves the prospects for wide industrial application of the VCS treatment.

\section{Conclusions.}

A fundamentally new method of vibrational-centrifugal strengthening treatment has been developed which belongs to the group of surface plastic deformation methods and features ability to dissipate considerable energy of deformation of strengthened part material. The method belongs to the group of dynamic surface strengthening methods; it provides for the thickness of strengthened layer of steel parts of $0.15 \div 0.20 \mathrm{~mm}$ on the outer surface and $0.10 \div 0.15 \mathrm{~mm}$ on the inner surface of cylindric long-length parts. Due to considerable energy of impact interaction between a tool and processed part material, there are formed residual compressive stresses of high gradient. As a result, this increases strength and reliability of strengthened parts including those of steel long-length drill and casing pipes.

For the first time, constructions of strengtheners for surface plastic deformation of outer and inner zones of long-length parts including those of drill and casing pipes have been proposed. The suggested strengtheners have a simple constructive design, are energy-efficient, do not require first line maintenance workers. Apart from strengthening drill and casing pipes, these constructions can be used for qualitative strengthening treatment of outer and inner zones of high-pressure pipes, outer surface of tank torsion shafts as well as torsion shafts of largecapacity self-propelled artillery weapons, inner surface of tank and artillery gun tubes of heavy gauge and others.

Along with increasing reliability and durability of parts strengthened by vibrational-centrifugal treatment, the strengthening technology considered makes it possible to decrease the part mass due to improving strength characteristics of the strengthened material. The volume of decreased mass of the parts due to qualitative strengthening treatment for drill and casing pipes of exploration wells makes $15 \div 20 \%$, which can provide up to 0.5 million US dollars of economic benefit for a $2 \div 3$-kilometre well as a result of decreasing consumption of drillstring pipe materials.

\section{Reference.}

1. Lototska, O. I., 2008. Increasing performance characteristics of printing machine parts. Technology and 
Technique of Typography, 3-4, pp. 16-20. DOI: 10.20535/2077-7264.2(28).2010.56079.

2. Kusyi, Ya. M. and Kuk, A. M., 2015. Developing the method of vibrational-centrifugal strengthening for technical support of machine part reliability. EasternEuropean Journal of Enterprise Technologies, 1/7(73), pp. 41-51. DOI: 10.15587/1729-4061.2015.36336.

3. Shyrokov, V. V., Kusyi, Ya. M., Aftanaziv, I. S., Borovets, V. M. and Kuk, A. M., 2010. Developing techniques for improving performance characteristics of oil and gas equipment parts. In: $10^{\text {th }}$ International Conference. Efficiency of implementing scientific, resource and industrial capacity in modern conditions. 2010. Slavske, Ukraine, pp. 243-246. DOI: 10.15587/1729-4061.2015.36336.

4. Kusyi, Ya. M. and Topilnytskyi, V. H., 2013. Research on the quality of the surface of vibrationally-displaced machine parts. Visnyk Natsionalnoho Universytetu “Lvivska Politekhnika”. Series "Optimization of Production Processes and Engineering Control in Machine Building and Tool Engineering”, 772, pp. 196-201.

5. Kusyj, Ya. and Topilnitskiyy, V., 2009. Calculatoions of vibratory-centrifugal strengthening treatment's dynamics by means of application software. In: Book of $a b-$ stracts XVII Polish-Ukrainian Conference on "CAD in Machinery Design-Implememtation and Educational Problems”, pp. 25-26. DOI: 10.15587/2312-8372.2015.3767.

6. Kusyj, J., Kuk, A. and Topilnytskyy, V., 2018. Vibratory-centrifugal strengthening's influence on failurefree parameters of drilling pumps bushings. Technology Audit and Production Reserves, 1(39), pp. 4-12. DOI: 10.15587/2312-8372.2018.123838.

7. Aftanaziv, I.S. and Shevchuk, L.I., 2018. Device for strengthening inner cylinder-shaped surfaces of long-length parts by surface plastic deformation. Ukraine. Pat. 116268. 8. Kuzin, O., Kusyj, J. and Topilnytskyy, V., 2015. Influence of technological heredity on reliability parameters products. Technology Audit and Production Reserves, 1(21), pp. 15-21. DOI: 10.15587/2312-8372.2015.37678. 9. Mironov, A. V. and Redreev, G. V., 2014. On strengthening the surface of parts by plastic deformation. Bulletin of Omsk State Agrarian University, 3(15), pp. 35-38. 10. Kravchuk, V.S., Dashchenko, A.F. and Lymarenko, A. M., 2016. Grapho-analytical method for determining strengthening effect of machine parts strengthened by surface method. In: Collection of research papers of Odesa State Academy of Technical Regulation, pp. 79-82.

11. Aftanaziv, I. S. and Shevchuk, L. I., 2018. Technique for strengthening inner cylinder-shaped surfaces of artillery gun tubes by surface plastic deformation. Ukraine. Pat. 116266.

\section{Вібраційно-відцентрове поверхневе зміцнення бурових і обсадних труб}

\section{І. С. Афтаназів, Л. І. Шевчук, Л. Р. Струтинська, O. I. Строган}

Національний університет „Львівська політехніка“, м. Львів, Україна, е-mail: ivan.aftanaziv@gmail.com

Мета. Створення нових конструкцій устаткування для зміцнення бурових і обсадних труб по- верхневим пластичним деформуванням, визначення конструктивних і технологічних параметрів вібраційно-відцентрового зміцнення довгомірних деталей.

Методика. На підставі теорії статичної подібності втомного руйнування запропонована методика визначення зменшення маси та матеріалоємності циліндричних деталей у результаті ефективного зміцнення їх внутрішніх і зовнішніх циліндричних поверхонь вібраційно-відцентровою обробкою.

Результати. На підставі досвіду промислового використання вібраційно-відцентрової обробки для зміцнення барабанів і реборд коліс літаків створені нові конструктивні схеми оригінальних пристроїв для зміцнення бурових і обсадних труб геологорозвідувальних свердловин. Відраційно-відцентрову зміцнювальну обробку доцільно використовувати на завершальному етапі виготовлення труб з метою підвищення їх надійності та довговічності, а також зменшення маси. Ця зміцнювальна технологія належить до групи динамічних методів поверхневого пластичного деформування, відрізняється спроможністю забезпечення значних, співрозмірних карбуванню, сил деформування матеріалу зміцнювальних деталей у поверхневих його прошарках. Для деталей із конструкційних сталей вібраційно-відцентрова зміцнювальна обробка забезпечує товщину зміцненого прошарку матеріалу в межах 0,15-0,20 мм, формування в ньому залишкових напружень стиску значного градієнту, підвищення поверхневої мікротвердості. Завдяки технологічному використанню значних сил інерції масивних зміцнювачів, що у процесі зміцнювальної обробки обкочуються по поверхні, забезпечується ефективне зміцнення металу оброблюваних поверхонь, формування в товщі матеріалу залишкових напружень стиску. Таке ефективне зміцнення як зовнішніх, так і внутрішніх протяжних поверхонь дозволяє на 15-20\% зменшити масу довгомірних сталевих деталей. Цим забезпечується певний економічний ефект, залежний від вартості матеріалу деталей. Уперше описані принципові схеми устаткування для зміцнення вібраційно-відцентровою обробкою внутрішніх та зовнішніх циліндричних поверхонь довгомірних деталей, у тому числі і бурових та обсадних труб. Запропоновані конструкції зміцнювального устаткування прості за конструктивною будовою, не передбачають потреби в обслуговуючому персоналі високої кваліфікації, високої продуктивності та енергоощадності.

Наукова новизна. Створені конструкції обладнання для зміцнення протяжних зовнішніх, а особливо, внутрішніх поверхонь циліндричних довгомірних деталей не мають аналогів у світовій практиці. Завдяки цим конструкціям суттєво розширюються галузі ефективного застосування поверхневого зміцнення.

Практична значимість. Полягає у зменшені матеріалоємності довгомірних деталей, що зміцнені на запропонованих конструкціях устаткування. На 
2-3-х кілометровій геологорозвідувальній свердловині зменшення внаслідок зміцнювальної обробки на 15-20 \% маси труб бурової колони дозволить економити близько 30-40 тон вартісної конструкційної сталі. Широке промислове впровадження вібраційно-відцентрового зміцнення та запропонованого устаткування для його реалізації дозволить також підвищити надійність і довговічність доволі широкого класу циліндричних довгомірних деталей.

Ключові слова: поверхневе зміцнення, довгомірна деталь, внутрішня поверхня, бурова труба

\section{Вибрационно-центробежное поверхностное упрочнение буровых и обсадных труб}

\section{И. С. Афтаназив, Л. И. Шевчук, Л. Р. Струтинская, О.И. Строган}

Национальный университет „Львовская политехника“, г. Львов, Украина, e-mail: ivan.aftanaziv@gmail.com

Цель. Создание новых конструкций оборудования для упрочнения буровых и обсадных труб поверхностным пластическим деформированием, определение конструктивных и технологических параметров вибрационно-центробежного упрочнения длинномерных деталей.

Методика. На основании теории статического подобия усталостного разрушения предложена методика определения уменьшения массы и материалоемкости цилиндрических деталей в результате эффективного упрочнения их внутренних и наружных цилиндрических поверхностей вибрационноцентробежной обработкой.

Результаты. На основании опыта промышленного применения вибрационно-центробежной обработки для упрочнения барабанов и ребер колес самолетов созданы новые конструктивные схемы оригинальных устройств для упрочнения буровых и обсадных труб геологоразведочных скважин. Вибрационно-центробежную укрепляющую обработку целесообразно использовать на завершающем этапе изготовления труб с целью повышения их надежности, а также уменьшение массы. Эта упрочняющая технология относится к группе динамических методов поверхностного пластического деформирования, отличается способностью обеспечения значительных, соразмерных чеканке, сил деформирования материала упрочняемых деталей в их поверхностных слоях. Для деталей из конструкционных сталей вибрационно-центробежная упрочняющая обработка обеспечивает толщину упрочненного слоя материала в пределах 0,15-
0,20 мм, формирование в нем остаточных напряжений сжатия значительного градиента, повышение поверхностной микротвердости. Благодаря технологическому использованию значительных сил инерции массивных упрочнителей, которые в процессе упрочняющей обработки обкатываются по поверхности, обеспечивается эффективное упрочнение металла обрабатываемых поверхностей, формирование в толще материала остаточных напряжений сжатия. Такое эффективное упрочнение как внешних, так и внутренних протяженных поверхностей позволяет на 15-20\% уменьшить массу длинномерных стальных деталей. Этим обеспечивается определенный экономический эффект, зависящий от стоимости материала деталей. Впервые описаны принципиальные схемы оборудования для упрочнения вибрационно-центробежной обработкой внутренних и наружных цилиндрических поверхностей длинномерных деталей, в том числе и буровых и обсадных труб. Предложенные конструкции упрочняющего оборудования простые по конструктивному строению, не предусматривают необходимости в обслуживающем персонале высокой квалификации, высокой производительности и энергосбережения.

Научная новизна. Созданные конструкции оборудования для упрочнения протяженных внешних, а особенно, внутренних поверхностей цилиндрических длинномерных деталей не имеют аналогов в мировой практике. Благодаря этим конструкциям существенно расширяются области эффективного применения поверхностного упрочнения.

Практическая значимость. Заключается в уменьшении материалоемкости длинномерных деталей, упрочнённых на предложенных конструкциях оборудования. На 2-3-х километровой геологоразведочной скважине уменьшение вследствие упрочняющей обработки на 15-20 \% массы труб буровой колонны позволит экономить около 30-40 тонн дорогостоящей конструкционной стали. Широкое промышленное внедрение вибрационно-центробежного упрочнения и предложенного оборудования для его реализации позволит также повысить надежность и долговечность довольно широкого класса цилиндрических длинномерных деталей.

Ключевые слова: поверхностное упрочнение, длинномерные детали, внутренняя поверхность, буровая труба

Рекомендовано до публікації докт. техн. наук В. В.Ступницьким. Дата надходження рукопису 07.10.17. 